REVISTA DE DERECHO UNED, NÚM. 12, 2013

\title{
REPORTAJES DE INVESTIGACIÓN CON CÁMARA OCULTA Y JURISPRUDENCIA CONSTITUCIONAL
}

\author{
INVESTIGATIVE REPORTS WITH A HIDDEN CAMERA AND \\ CONSTITUTIONAL JURISPRUDENCE
}

\section{FERNANDo Gómez SÁEz}

Licenciado en Ciencias de la Información y en Derecho, doctorando del Departamento de Derecho Constitucional de la Universidad Nacional de Educación a Distancia (UNED)

Resumen: A finales de 2011 el Tribunal Constitucional todavía no se había pronunciado sobre ningún caso que abordase la legitimidad constitucional del empleo de la cámara oculta en el ámbito periodístico. Por fin llegó la esperada Sentencia del Alto Tribunal español, en enero de 2012, en la que se resolvió el recurso de amparo planteado por Canal Mundo Producciones Audiovisuales, S. A. y la Televisión Autonómica Valenciana, S. A., contra la Sentencia del Tribunal Supremo en la que se interpretó que se había producido una intromisión ilegítima en los derechos a la intimidad y a la propia imagen de la naturista Rosa Fornés Tamarit. El pronunciamiento consideró que la utilización de grabaciones clandestinas con finalidad periodística puede tener consecuencias negativas sobre los derechos de la personalidad.

Palabras clave: Cámara oculta, derecho a la libertad de información, derecho a la información, ponderación, veracidad, interés general, relevancia pública de la información, falsedad de consentimiento, engaño, derecho a la intimidad, derecho a la propia imagen.

Abstract: At the end of 2011, the Spanish Constitutional Court had not ruled on any case regarding the constitutional rights of journalist to use hidden cameras. Finally, the awaited sentence of the 
High Spanish Court, came out on January of 2012, and solved the claim made by Canal Mundo Producciones Audiovisuales, S. A. and the Televisión Autonómica Valenciana, S. A., against the sentence or the Supreme Court, which had interpreted that an illegitimate interference had taken place in the rights to privacy and to the own image of the naturist Rosa Fornés Tamarit. The Constitutional Court resolution stated that the use or furtive recording for journalistic purposes can have negative consequences on the rights of the rights of the personality.

Keywords: Hidden camera, right to freedom of the information, right to the information, balancing, accuracy, general interest, public relevance of the information, false consent, deception, privacy, right to self-image.

Recepción original: 26/04/2013

Aceptación original: 29/04/2013

Sumario: I. Introducción. II. Cuestiones formales. III. Reacciones a la STC 12/2012. IV. Análisis de la STC 12/2012. V. Fundamentos Jurídicos de la STC 12/2012. V.1. FJ 1: Se alega ponderación y proporcionalidad no ajustadas a jurisprudencia. V.2. FJ 2: Se cuestionó si se vulneró el derecho a la libertad de información. V.3. FJ 3: La cámara oculta por primera vez. V.4. FJ 4: Veracidad, interés general y relevancia pública. V.5. FJ 5: Valoración del derecho a la intimidad personal y a la propia imagen. V.6. FJ 6: La protección de los derechos de la personalidad. V.7. FJ 7: Por fin la ponderación entre los derechos fundamentales en conflicto. V.8. Resumen de los Fundamentos Jurídicos. VI. A modo de conclusión. VII. Bibliografía.

\section{INTRODUCCIÓN}

La Sentencia del Tribunal Constitucional (en adelante STC) 12/2012, de 30 de enero, confirmó el pronunciamiento del Tribunal Supremo (TS) en el que se revocaron los fallos tanto del Juzgado de Primera Instancia como de la Audiencia Provincial (AP) de Valencia. En las dos últimas instancias se interpretó que se había producido una intromisión ilegítima posterior al emitirse sin autorización imágenes captadas con cámara oculta en el consultorio privado de la esteticista Rosa Fornés Tamarit, de la que se pretendía demostrar sus prácticas poco profesionales. 


\section{CUESTIONES FORMALES}

La STC 12/2012 fue dictada por la Sala Primera del Tribunal Constitucional (TC), compuesta por su presidente, Pascual Sala Sánchez, y los magistrados Javier Delgado Barrio, Manuel Aragón Reyes, Pablo Pérez Tremps y Adela Asua Batarrita contra la Sentencia número 1233/2009, de 16 de enero, y la providencia de 14 de abril de 2009 de la Sala de lo Civil del TS, dictadas en el recurso de casación número 1171/2002. Decidieron por unanimidad (al igual que había ocurrido con la STS que enjuiciaban) denegar la totalidad de los amparos solicitados. La resolución está compuesta por 11 Antecedentes y 7 Fundamentos Jurídicos (FJS). No se presentó recurso sobre la STC ante el Tribunal Europeo de Derechos Humanos (TEDH) de Estrasburgo.

\section{REACCIONES A LA STC 12/2012}

El pronunciamiento judicial sobre nuestro objeto de estudio supone una aportación de gran valor a la investigación, pero al mismo tiempo se pueden plantear dificultades añadidas por estar analizando una realidad que todavía no tiene un sedimento sólido.

Habrá que aumentar las precauciones para evitar cualquier tipo de precipitación. Así ha ocurrido con algunas interpretaciones realizadas con urgencia en los medios de comunicación tras conocerse el fallo. Hay dos motivos que pueden servir como excusa para este hecho. La ansiedad acumulada por el carácter pionero del pronunciamiento del TC sobre el uso de la cámara oculta, así como que el centro neurálgico de la cuestión afecta a la profesión periodística.

El consumidor de información está habituado a que la noticia se le presente en los medios tradicionales, ya sea a través de un soporte escrito, auditivo o audiovisual, mediante un titular. La limitación de espacio o de tiempo provoca una servidumbre similar a los 140 caracteres de la red social Twitter, lo que se puede traducir en una falta de precisión a la hora de resaltar lo más importante que contiene el cuerpo informativo.

Lucrecio Rebollo Delgado no parece sorprendido por las diferentes interpretaciones suscitadas: "si hay alguna conclusión que haya podido extraer en mis más de 25 años de estudio del Derecho Constitucional es que no hay nada más incompatible en nuestro mundo de la información y la comunicación que un titular informativo y 
una sentencia judicial"1. Ya se trate de titulares propiamente dichos o de sumarios, vamos a recoger en el siguiente párrafo un resumen de las principales ideas que extrajo la prensa española escrita de la Sentencia de referencia.

Se afirma sin fisuras que el TC declara ilegítimo el uso de la cámara oculta por el engaño que realiza el periodista. Otras conclusiones también en un sentido neutro indican que el informador debe estar, en criterio del Alto Tribunal, tan limitado en su trabajo como la policía o los jueces. Así como que la Sentencia provoca división en la profesión.

En cuanto a las reacciones de los sectores implicados, la Federación de Asociaciones de Periodistas de España (FAPE) manifiesta que supone un daño para la investigación de calidad. Por último, se puede constatar un predominio de aceptación en el mundo judicial, como un medio de frenar el llamado amarillismo², que, según Jesús Timoteo Álvarez, está marcado desde sus inicios «formalmente por estos dos conceptos: el dominio de un sensacionalismo exagerado, que convierte el periódico en algo gritón, de colorines, sin fines fuera de sí mismo, y al lector en mero engullidor de sensaciones impresas» ${ }^{3}$.

\section{ANÁLISIS DE LA STC 12/2012}

Ya hemos señalado que la Sentencia tiene 11 antecedentes. Vamos a detenernos a continuación en los aspectos destacados que consideramos de interés por su trascendencia posterior. En el 3. ${ }^{\circ} \mathrm{b}$ ) se afirma que, además de emitirse en la cadena de televisión Canal 9 la grabación de imágenes y de voz de la esteticista captada en su

1 Rebollo DElgado: «Ni prohíbe el uso de cámaras ocultas, ni cercena el periodismo de investigación», en: Cuadernos de Periodistas, número 24, Asociación de la Prensa de Madrid, Madrid, 2012, pág. 42.

2 El origen del amarillismo está ligado a William R. HEARST, un californiano nacido en 1863, rico, controvertido y expulsado de la Universidad de Harvard, que compró en 1885 en Nueva York el periódico en quiebra Morning Journal (curiosamente había sido fundado por AlBert, el hermano de Josept Pulitzer, que da nombre a los más prestigiosos premios periodísticos en Estados Unidos para publicaciones en lengua inglesa). HEARST rebautizó el diario con el nombre de New York Journal, con el que ha pasado a la historia como ejemplo de periodismo amarillo, al trabajar con el rumor y la invención de noticias, que no siempre son desmentidas en el siguiente número, en busca del aumento de ventas sin prestar demasiada atención a la dignidad y el respeto al lector.

3 Timoteo Álvarez, J.: Historia y modelos de la comunicación en el siglo XX. El nuevo orden informativo, Ariel Comunicación, Barcelona, 1987, pág. 64. 
clínica, se desarrolló dentro del mismo programa una tertulia sobre la existencia de falsos profesionales que trabajan en el mundo de la salud. Intervinieron un representante de la Asociación Española de Fisioterapeutas, el letrado que defendió a Fornés Tamarit en el proceso penal en el que fue condenada por un delito de intrusismo al haber ejercido como fisioterapeuta sin poseer el título habilitante, además de una paciente que en una solo ocasión había sido atendida por la supuesta profesional.

En el apartado 3.c) se recuerda que la actora entendió que se había producido por parte tanto de los medios de comunicación como de las tres personas físicas que intervinieron en la emisión una lesión de sus derechos al honor por los comentarios en el programa, así como también de sus derechos a la intimidad y a la propia imagen, en atención a la captación y publicación de imágenes. Solicitó una indemnización de setenta y cinco millones de pesetas (cuatrocientos cincuenta mil, setecientos cincuenta y nueve euros con 7 céntimos) y la difusión íntegra de la sentencia que se obtuviera. El Juzgado de Primera Instancia número 17 de Valencia desestimó la demanda el 26 de junio de 2001 al interpretar que la simulación de la situación de la periodista con la cámara oculta respondía al ejercicio del periodismo de investigación y no era precisa la revelación de su identidad profesional, mientras que las opiniones vertidas en la tertulia tenían un ánimo puramente informativo.

En el siguiente párrafo 4.d) se relata que el recurso de apelación interpuesto por Fornés Tamarit fue desestimado también en su integridad por la sección sexta de la AP de Valencia el 24 de enero de 2002. Se argumentó en el pronunciamiento que el reportaje elaborado con la cámara oculta cumplía con todos los requisitos de veracidad, objetividad, interés general y propósito esencialmente informativo, que le hacían merecedor de protección constitucional, con lo que no atentaba contra ningún derecho amparado por la Constitución española (CE). Por su parte, se consideró que las opiniones vertidas por los contertulios en el programa televisivo habían sido encuadras correctamente dentro de la doctrina de información neutral por la Sentencia que entonces era enjuiciada, al responder al ejercicio de la libertad de expresión sobre unos hechos veraces y sin que en ningún momento se atentase contra el honor de la parte apelante, pues las expresiones empleadas no resultaban insultantes o vejatorias.

Como refleja el apartado 3.e) la demandante insistió y obtuvo su objetivo en el recurso de casación en el que alegó infracción del 
artículo $18.1 \mathrm{CE}$ en relación con el artículo 7, apartados 1, 5 y 7 de la Ley Orgánica (LO)1/1982, de 5 de mayo. El pronunciamiento de la Sala de lo Civil del Tribunal Supremo, con fecha de 16 de enero de 2009, declaró que procedía estimar parcialmente el recurso de casación por infracción del artículo 18.1 de la Norma Suprema, en relación con el artículo 7, apartados 1, 5 y 7 de la LO 17/1982, de 5 de mayo. De este modo la Sentencia de la Primera Instancia, quedaba sin efecto y, en lugar de ella, estimó en parte la demanda interpuesta contra todos los sujetos pasivos salvo la paciente (en lo que a esta se refiere se produjo la desestimación con imposición de las costas correspondientes a la actora). Se les condenó de forma solidaria a la indemnización de treinta mil cincuenta euros con setenta y un céntimos (cinco millones con diecisiete pesetas), es decir, 15 veces menos que lo solicitado en la demanda, y sin pronunciamiento condenatorio en costas. La sanción a la productora audiovisual fue por la grabación con instrumentos emboscados y a la televisión autonómica por la difusión de dichas imágenes en un programa sobre falsos profesionales en el mundo de la salud.

La Sala $1 .^{\mathrm{a}}$ del TS negó que se hubiera producido una vulneración del derecho al honor, pero sí admitió una intromisión ilegítima con respecto al derecho a la intimidad (tanto por la grabación en la consulta como por la posterior emisión en televisión de las imágenes grabadas), pues entiende que del reportaje no se deduce con claridad suficiente que la actora ejerciera como fisioterapeuta sin título, ni se aclara por qué fue ella la persona elegida para dar un ejemplo público. A mayor abundamiento, tampoco se justifica que el material obtenido y dado a conocer a la audiencia tuviera la relevancia suficiente como para sacrificar un derecho fundamental de la personalidad. La Sentencia admite que hubiera bastado con entrevistar a los clientes.

También fue estimada la solicitud de infracción del derecho a la propia imagen, puesto que en ninguna de las dos fases de la actuación periodística de grabación y emisión la actora pudo ejercer su derecho a decidir y al consentimiento expreso, que exige el artículo 2.2 en relación con el artículo 7.1 de la LO 1/1982. Se reprueba también la utilización de la imagen de la actora al tiempo que los tertulianos manifestaban su opiniones, pues la convirtió en un elemento fundamental de la información cuando su carácter debería haber sido solo accesorio, de acuerdo con el artículo 8.2. c) también de la LO 1/1982.

El Antecedente 3.f) informa que el TS declaró el 14 de abril de 2009 que no había lugar al incidente de nulidad de actuaciones plan- 
teado por las dos empresas de comunicación que formaban parte del proceso puesto que el único fundamento que se advertía era la disconformidad con los razonamientos de la Sentencia cuestionando el juicio de ponderación y proporcionalidad entre el derecho a la libertad de información y los derechos a la intimidad y la propia imagen.

La Sentencia que analizamos recoge en su Antecedente 4 la argumentación de Canal Mundo Producciones Audiovisuales, S.A., que se basa en la pretendida prevalencia del derecho a informar del artículo 20.1.d) CE, que no debería verse limitado per se por el empleo de la cámara oculta, sobre los derechos individuales de la persona, en concreto los recogidos en el precepto 18.1 también de la Carta Magna. A favor de su derecho, recuerda la concurrencia en la información enjuiciada de los requisitos de veracidad, interés general y fin informativo, que exigen tanto la jurisprudencia constitucional como la europea. Por último, se aduce que la Sentencia del Tribunal Supremo recurrida genera una inseguridad jurídica para todos los profesionales que se dispongan a producir reportajes de investigación en televisión con la técnica de la cámara oculta.

Por su parte, en el Antecedente 5 se recogen las alegaciones de Televisión Autonómica Valenciana, S.A., que también transcurren por la consideración de que se ha vulnerado el derecho a comunicar o recibir libremente información veraz por cualquier medio de comunicación. Se defiende que el resultado es la consecuencia de una ponderación errónea realizada por el Tribunal de casación entre los derechos a la intimidad y a la imagen, por un lado, y el derecho a la información, por otro. También recurre a la doctrina constitucional y jurisprudencia europea para argumentar que exigir el consentimiento siempre de quien es grabado puede suponer la negación del periodismo de investigación, que, recuerda, está avalado por el Tribunal Europeo de Derechos Humanos (TEDH), en particular con su Sentencia de 23 de septiembre de 1994 (Jersild contra Dinamarca), donde se dictaminó que la elección de las técnicas informativas a emplear es una decisión que corresponde a los periodistas.

La postura del Ministerio Fiscal es recogida en el Antecedente 9. Con sendos escritos registrados los días 3 y 8 de marzo de 2001 interesó que se desestimaran los amparos. Su primer argumento de peso consistió en recordar que la libertad de información no goza de un valor preferente o superior frente a otros derechos fundamentales, de modo que las intromisiones que se produzcan en ellos han de ser congruentes con la finalidad perseguida. Niega relevancia en el caso a los criterios de veracidad y la teoría del reportaje neutral, pero se 
la concede al de la relevancia pública de la información grabada y difundida, que debe ir más allá del simple interés del público o la mera satisfacción de la curiosidad ajena.

El Fiscal avala constitucionalmente el juicio de ponderación realizado por el TS, que conduce a declarar la trascendencia del material obtenido y emitido, por lo que la intromisión realizada en la esfera de la intimidad mediante el empleo de una cámara oculta ha de considerarse ilegítima. La supuesta relevancia pública pierde consistencia al centrarse el reportaje en la actuación de una única persona. Niega que en este caso se puedan defender las grabaciones sin consentimiento con el sustento del periodismo de investigación. Equiparación que califica como simplista al encontrar en la información examinada elementos de superficialidad, banalización y trivialización con un intento mucho más focalizado en crear una polémica que otorgue cuotas altas de audiencia que en una pretensión tan democrática como sería la formación de una opinión pública libre.

En ambos escritos el Ministerio Fiscal rechaza de plano la tesis de los recurrentes consistente en defender que corresponde únicamente a los profesionales de la Información la elección de fuente y medios técnicos a utilizar por el peligro a que esto desembocase en una falta de protección hacia los terceros. Sostiene que estas decisiones serán susceptibles posteriormente del control constitucional. Y mucho más, argumenta, cuando se trata de una cámara oculta, que solo debería utilizarse cuando exista en el horizonte un interés general suficientemente cualificado y no se disponga de otros medios para obtener dicho registro periodístico. Circunstancias que, entiende, no se producen en el supuesto que se examina.

Tampoco considera que deba prosperar el amparo por la supuesta vulneración del derecho a la libertad de información en relación con el derecho a la propia imagen, puesto que a la esteticista no solo se le grabó sin su consentimiento, sino que tampoco tuvo oportunidad de prestarlo para la difusión en la tertulia de televisión, donde se le pudo identificar correctamente por la audiencia. No se utilizó ninguna técnica para ocultar o distorsionar su rostro, más bien al contrario. La colocación de su imagen en algunos momentos de la emisión parecía responder a un intento adicional de atraer la atención de cada espectador, pues era frecuente encontrarla en planos principales.

El objeto de los dos últimos Antecedentes, 10 y 11, fue, respectivamente, informar sobre la acumulación del recurso de amparo más moderno al más antiguo para proceder a una resolución conjunta, 
decidida por Auto de fecha 21 de noviembre de 2011, así como el acuerdo por providencia de 26 de enero de 2012 de la señalización del día 30 de enero del mismo mes y año para la deliberación y fallo de la Sentencia.

\section{FUNDAMENTOS JURÍDICOS DE LA STC 12/2012}

Procedemos a continuación al comentario individualizado de los 7 FJS que componen la Sentencia que analizamos, en la que por primera vez el TC se pronunció de un modo conjunto sobre las peculiaridades que presenta una grabación videográfica íntegra. Como un proceso informativo más, tiene en común con el resto de ellos las tres fases que ha señalado Joaquín Urías, con sus correspondientes valoraciones jurídicas. Estas son: "la recogida de datos, la elaboración de esos datos para crear esa información y difusión”"

\section{V.1. FJ 1: Se alega ponderación y proporcionalidad no ajustadas a la jurisprudencia}

El Fundamento Jurídico 1 es el más breve de todos, dado su carácter introductorio. En él se informa de lo que el lector ya conoce, la posición de los recurrentes sobre la vulneración de su derecho a comunicar libremente información veraz. La justifican por la desatención en la Sentencia que se examina de los criterios de ponderación y proporcionalidad en los términos ajustados a la jurisprudencia marcada por el Alto Tribunal y el TEDH a la hora de valorar el derecho reclamado frente a los derechos a la intimidad y la propia imagen. Se recuerda también la postura a favor de la desestimación total del Ministerio Fiscal.

\section{V.2. FJ 2: Se cuestiona si se vulneró el derecho a la libertad de información}

Los derechos de la personalidad con respecto al honor, la intimidad personal y la propia imagen están agrupados en el artículo 18.1 CE y la LO 1/1982 está dedicada a todos ellos, pero en el Fundamento Jurídico 2 de la Sentencia que ahora manejamos, el TC informa que el derecho al honor queda al margen de la valoración, dado que en nin-

\footnotetext{
4 URÍAs, J.: Lecciones de Derecho de la Información, Tecnos, Madrid, 2009, pág. 77.
} 
guna de las tres instancias judiciales anteriores que han conocido la controversia se ha declarado vulnerado. A la vista de los acontecimientos, solo habría sucedido tal hecho si en la emisión televisiva alguno de los contertulios al referirse a la naturista hubiera proferido insultos o expresiones ofensivas.

Acotada definitivamente la cuestión, el Tribunal ad quem reconoce que el objeto de su actuación es resolver si en la Sentencia del TS a la hora de ponderar todos los derechos fundamentales en conflicto se vulneró o no el artículo 20.1.d) constitucional en su concreción de derecho a la libertad de información. El punto de partida es la reiterada doctrina con la que cuenta el TC, de la que recuerda un pronunciamiento reciente: la Sentencia del TC 23/2010, de 27 de abril. Observamos una gran semejanza con el asunto que se analiza, puesto que fue pronunciada como resolución a un recurso de amparo promovido por HF Revistas, S.A., que reclamó una supuesta vulneración de los derechos a la libertad de expresión y a la tutela judicial efectiva (artículo 24 de la Constitución). El TS y la AP de Madrid habían estimado la demanda de Isabel Iglesias Preysler al entender que no se había respetado su derecho a la propia imagen a raíz de la publicación de un reportaje caricaturesco en la revista Noticias del Mundo. Los hechos consistieron en la manipulación de una fotografía con ánimo de burla y sin consentimiento de la afectada.

En este FJ 2 se cita textualmente también el segundo de la STC 23/2010 para informar que la condición de garante máximo de los derechos fundamentales implica una obligación al TC que no se reduce a examinar la suficiencia y consistencia de la motivación de las resoluciones judiciales, a los ojos del artículo 24 constitucional, sino que debe resolver la confrontación entre los derechos implicados, de acuerdo con el contenido que la Norma Suprema ha concedido a cada uno. Para ello tiene atribuida la facultad de aplicar criterios distintos a los aplicados por los órganos jurisdiccionales, puesto que las razones de estos no le vinculan, aunque sí los hechos que se declaran probados en la vía judicial, tal y como establece el artículo 44.1.b) de la Ley Orgánica del Tribunal Constitucional 2/1979, de 3 de octubre, donde se prohíbe al Alto Tribunal que entre a conocer.

\section{V.3. FJ 3: La cámara oculta por primera vez}

Una vez expuestos las criterios, condicionantes y privilegios con los que cuenta el TC, en el FJ 3 se produce una aproximación más 
al objeto de estudio al referirse ya a la doctrina fijada por el propio Tribunal en los juicios de ponderación entre el derecho a la libertad de información y los otros derechos fundamentales a la intimidad personal y a la propia imagen, o con solo uno de ellos. Se recuerda la particularidad de este caso, pues obliga por primera vez a pronunciarse sobre el uso de una cámara oculta que ha grabado imágenes y voces por medio de la intromisión en una esfera privada donde ha captado una conversación desarrollada en un espacio donde se realiza una actividad profesional.

\section{V.4. FJ 4: Veracidad, interés general y relevancia pública}

En el FJ 4 el TC realiza ya un amplio recurso a la jurisprudencia al citar tres Sentencias suyas, junto a una STEDH, de la que hablaremos más adelante. La primera de ellas es para poner de manifiesto la peculiar posición que ocupa en el ordenamiento jurídico español el derecho a la libertad de información, puesto que no solo protege un interés individual, sino que también se erige en reconocedor y garante para el mantenimiento de una opinión pública libre, que como ya rezaba en su FJ 3 la célebre STC 68/2008, de 23 de junio (la primera que se menciona en la Sentencia que se comenta), está «indisolublemente unida al pluralismo político propio del Estado democrático».

Es sabido que ningún derecho fundamental tiene carácter ilimitado. También lo tiene la protección especial que engloba al derecho a la libertad informativa. El TC afirma que su labor previa ha ido perfilando una doble clase de límites, que bautiza como inmanentes y externos. Estos últimos son exactamente los que describe el artículo 20.4 CE y que ya han sido citados antes.

Para hablar del primer tipo de limitaciones, la veracidad y el interés general o relevancia pública de la información, se apoya tanto en el mismo FJ 3 de la última STC mencionada como en la STC 129/2009, de 1 de junio, FJ 2, donde también se alude a aquella cita $^{5}$ para referirse al grado de diligencia exigido para considerar una información veraz. Se trata de un pronunciamiento que llegó como consecuencia del recurso de amparo (desestimado después en su totalidad) planteado por Editorial Prensa Alicantina, S.L. y dos

5 En el FJ 2 de la STC 129/2009, de 1 de junio, se incorpora el fragmento de la STC 68/2008, de 23 de junio, FJ 3, donde se afirma lo siguiente sobre la relevancia de la veracidad informativa: no es que a posteriori se pruebe en un proceso la realidad de los hechos, sino el grado de diligencia observado para su comprobación con anterioridad a la publicación de aquéllos. 
personas físicas más al entender que se habían vulnerado los derechos fundamentales reconocidos en el artículo 20.1.a) y d) CE por no realizar una ponderación de los intereses en conflicto de acuerdo con los términos exigidos por la jurisprudencia constitucional. La conclusión del Alto Tribunal es diáfana: si falta alguno de los dos requisitos, el respaldo constitucional a la libertad de información deja de estar operativo.

El deber de diligencia que recae sobre el informador para que todo aquello que transmita como hechos haya sido previamente contrastado con datos objetivos está avalado por una amplia jurisprudencia, que se inició con la STC 6/1988, y a la que siguen las SSTC 28/1996, de 26 de febrero; 52/1996, de 26 de marzo; 3/1997, de 13 de enero; y 144/1998, de 30 de junio.

Con respecto a la relevancia pública informativa, el TC sostiene que para establecerse la protección constitucional se ha de tener siempre presente la capacidad de los hechos difundidos para contribuir a la formación de la opinión pública. Y para ello, o bien están conectados a la proyección pública de la persona a la que aluden o lo están a alguna de las características del hecho en el que dicho individuo haya estado involucrado. Llegado este punto se apoya en la STC 29/2009, de 26 de enero, que fue dictada con ocasión de un recurso de amparo, que sería concedido por el TC por unanimidad, por vulneración del artículo 20.1.a) CE. Lo presentaron el periodista de investigación Eduardo Inda Arriaga, (a la sazón director del periódico El Mundo-El día de Baleares), Unidad Editorial, S.A., y Rey Sol, S.A. En concreto el TC cita el FJ 4, el penúltimo de la Sentencia, que concluye recordando la relevancia que tiene para la protección constitucional los cauces a través de los cuales se transmite la información, tal y como ya quedó fijado en la STC 105/1990, de 6 de junio, FJ 4.

Las últimas líneas del FJ 4 de la STC que estamos comentando están dedicadas a la jurisprudencia continental, en particular se menciona la STEDH de 24 de junio de 2004, Von Hannover contra Alemania. En este pronunciamiento se defendió la postura de que ni siquiera la vida privada de las personas públicas y en lugares abiertos al público tiene interés general. En consecuencia su derecho a la vida privada debe prevalecer no solo sobre lo que puede considerarse curiosidad o morbo, sino incluso sobre un pretendido interés público que también puede calificarse como comercial.

Conviene recordar que el TC estaba analizando el derecho a la vida privada de una persona que si bien no era alguien desconocida, 
pues tenía una consulta abierta al público, su repercusión debe permanecer más próxima a la de personas poco relevantes socialmente que alguien que entra en el calificativo de famoso a todos los efectos, como es Carolina de Mónaco. En cuanto al lugar en el que ocurrieron los hechos, aún tratándose de un espacio al que accedían sus pacientes, lo hacían de forma individualizada y, como es evidente, sin que ni siquiera el resto de ellos pudieran tener acceso ni visual ni auditivamente a lo que allí ocurría. Por tanto, distaba mucho de ser un lugar abierto al público como donde habían sido tomadas las fotografías a la princesa monegasca.

El TC cita los apartados 65 y 76 de la STEDH, en los que se debate sobre el interés público general, un claro ejemplo de concepto jurídico indeterminado. En el primero de ellos se afirma sin fisuras que, a pesar de la indiscutible notoriedad de la demandante en dicho proceso, la publicación de fotografías y artículos sobre ella en ningún caso puede contribuir a fomentar un debate de interés general para la sociedad, sino más bien satisfacer la curiosidad de un público muy concreto sobre aspectos de su vida privada 6 .

En el siguiente apartado mencionado se aborda desde otra línea de penetración el concepto de interés general. Ahora con la idea de ponderar o establecer un equilibrio entre la vida privada y la libertad de expresión. Aquí se llega a idéntica conclusión con respecto a la inexistente aportación de las fotografías y artículos publicados sobre Carolina de Mónaco al pretendido debate. El motivo es que la demandante no desempeña funciones oficiales y todos los documentos periodísticos difundidos se referían a su vida privada.

\section{V.5. FJ 5: Valoración del derecho a la intimidad personal y a la propia imagen}

Hemos llegado al momento crucial en la argumentación de la STC 12/2012, el que representan los tres últimos FJS 5, 6 y 7, que son además los de mayor extensión. El primero se inicia con una delimitación de cuál debe ser la participación en la ponderación definitiva por este lado. En concreto, los derechos a la intimidad personal y a la propia imagen. Tanto estos dos, como el aquí descartado derecho al honor (por no valorarse en este punto el contenido informativo

6 La jurisprudencia que se cita al final de este apartado 65 tiene su origen en España: Jaime Campmany y Díez Revenga y Juan Luis López-Galiacho Perona contra España (dec), número 54224/2000, 12.12.2000 y Julio Bou Gibert y El Hogar y La Moda contra España (dec), número 14929/2002, 13.05.2003, y Prisma Press.

(C) UNED. Revista de Derecho UNED, núm. 12, 2013 
preciso, sino la forma y el lugar donde se ha obtenido; en caso contrario, lo trascendente sería el grado de veracidad de la información), no solo comparten precepto constitucional, sino que además cuentan en el ordenamiento español con sustantividad y contenido propio cada uno de ellos.

Comienza el TC con la valoración sobre el derecho a la intimidad y la primera Sentencia de una completa relación que cita es muy reciente: la STC 77/2009, de 23 de marzo, FJ 2. Fue dictada para dar respuesta denegatoria a un recurso de amparo interpuesto por Ediciones Zeta, S.A., por entender que se habían vulnerado los derechos al honor, la intimidad y a la propia imagen. Se recuerda que dicho derecho que se considera en nuestra cultura como necesario para mantener una mínima calidad de la vida humana y con el que se puede imponer a terceros que no se entrometan en nuestra esfera íntima ni utilicen lo conocido en ella, puede ceder ante otros derechos como el derecho a la información, pero se precisa no solo que esta sea veraz, sino que esté referida a hechos noticiables. Este es, pues, una vez más el lugar de la discusión jurídica planteada.

Es pacífica la consideración de aquellos escenarios que entran en la condición de íntimos, como es el domicilio, pero la jurisprudencia europea ha desarrollado una interpretación extensiva, que no la limita al espacio doméstico, sino que incluye aquellos lugares en los que el individuo desarrolla su vida personal, en concreto donde ejerce su profesión. La labor jurisprudencial en esta línea se inició con la STEDH de 16 de diciembre de 1992, Niemietz contra Alemania, apartado 29. Este caso se planteó porque un Tribunal de Munich en el desarrollo de unas diligencias penales seguidas contra un tercero ordenó una investigación en el despacho profesional de un abogado ante las sospechas de que pudiera existir una relación entre ambos individuos. Tras el registro en su bufete, el letrado reaccionó alegando que las autoridades alemanas no habían respetado el artículo 8 de la Convención de Roma, donde se garantiza el respeto de la vida privada y del domicilio y obtuvo una Sentencia estimatoria.

Queda claro que la protección de la vida privada que concede el TEDH supera la amplitud de la esfera familiar para abarcar ámbitos en los que se produce una interacción social. Recuérdese que, independientemente de que careciera de la titulación exigible, el lugar donde se realizó la grabación con cámara oculta a la naturista fue en el ámbito privado del despacho profesional en el que esta pasaba consulta con sus pacientes y donde, por tanto, contaba con una presunción de discrecionalidad razonable como para pensar que todo lo 
que allí ocurriera y se comentase no sería difundido sin su consentimiento previo. Todo ello a pesar de que el contenido de la conversación no pueda calificarse como secreto y en ella tan solo intervinieran dos personas, puesto que es posible una privacidad compartida.

Tampoco puede prosperar en el supuesto que comentamos, en opinión del TC, el argumento de los recurrentes en amparo, que sí había sido aceptado por la AP de Valencia en el recurso de apelación, sobre que no se debería considerar una vulneración del derecho a la intimidad cualquier conversación que haya sido grabada por uno de los interlocutores, pero no por un tercero no interviniente. Dicho razonamiento se apoya en la STC 114/1984, de 29 de noviembre, en la que se denegó un recurso de amparo por vulneración de los derechos fundamentales reconocidos en los artículos 18.3 CE (secreto de las comunicaciones) y 24. 2 CE (proceso judicial con todas las garantías), que traía su causa en un despido del actor.

Aunque la STC 114/1984 no apreció infracción en la grabación de uno de los dos participantes en un diálogo telefónico sin consentimiento de la otra parte, es cierto que en su FJ 7 dejó abierta la posibilidad a que sí pudiera producirse una infracción al artículo 18.1 CE en el caso de que lo así transmitido a otros entrase en la esfera «intima» del interlocutor.

Con la argumentación que se acaba de resumir el TC resuelve la duda acerca de si el lugar en el que se grabó con cámara oculta merece gozar de la protección que concede el derecho a la intimidad. El siguiente paso es realizar el mismo proceso con el derecho a la propia imagen. Aquí el Tribunal ad quem también cita en primer lugar su jurisprudencia más reciente, la STC 23/2010, a la que ya hizo mención en el FJ 2 de la Sentencia que analizamos. En concreto ahora la referencia es al FJ 4. Se justifica aquí la protección que cada persona tiene con respecto a la información gráfica de sus rasgos físicos y que se materializa en la posibilidad de negarse a que sea obtenida y publicada por un tercero no autorizado. Todo ello siempre que tal actuación no descanse en el ejercicio de otro derecho fundamental.

Recuerda el TC que ya en su STC 117/1994, de 25 de abril, FJ 3, delimitó las parcelas más características que integraban este derecho reconocido junto a los derechos al honor y a la intimidad y que no eran otras que la imagen física, la voz y el nombre. Todo ello porque la libertad de las personas se ejerce en el mundo físico mediante la actuación del cuerpo y de sus propias cualidades. La protección de la imagen así expresada se convierte también en un modo de salva- 
guardar el ámbito de la intimidad. La resolución que ha sido citada concluyó con la denegación del amparo solicitado por la actriz madrileña Ana García Obregón, que se oponía a la desestimación de un recurso de casación por el TS en un litigio en el que estaban inmersos la totalidad de los derechos del artículo 18.1 CE.

Queda claro que al igual que el derecho a la intimidad, el derecho a la propia imagen tiene los límites en la misma voluntad de su titular. En palabras de Carrillo: «el derecho a la propia imagen proporciona a su titular la potestad de autodeterminación sobre el flujo de información gráfica generado por sí mismo, a fin de controlar su reproducción y difusión ${ }^{7}$. Como ha afirmado Amelia Pascual Medrano, es un derecho que incluso va más allá de la representación gráfica de la vida humana al abarcar incluso la voz y el nombre de las personas, aunque con respecto a ellos, el titular «únicamente dispone de la facultad de decidir sobre su utilización comercial. La voz y el nombre se protegen así solo en cuanto se utilicen con fines comerciales, publicitarios o similares» ${ }^{8}$.

Para concluir este FJ 5, el intérprete supremo de la CE recuerda que en el caso sometido a examen se captaron sin su consentimiento tanto la imagen como la voz de la naturista, de modo que el aumento de las posibilidades de ser identificada por la audiencia provocó no solo que se produjera una vulneración del derecho a la propia imagen sino también que este alcanzara con una intensidad alta.

\section{V.6. FJ 6: La protección de los derechos de la personalidad}

Entramos en el FJ 6 ya con la constatación de que efectivamente se han vulnerado los derechos fundamentales alegados por la profesional grabada ya desde su demanda de instancia. El siguiente paso es abordar el conflicto entre ellos y la libertad de información. Sabemos que ningún derecho fundamental es ilimitado, pero en el caso de este último la CE señala en su artículo 20.4 que los derechos de la personalidad del artículo 18.1 se convierten especialmente en límites externos, junto a la protección de la juventud y de la infancia.

Al analizar la resolución del TC, Carrillo ha afirmado lo siguiente sobre esta cuestión: «No es excusa suficiente que el periodista pueda decidir ilimitadamente sobre los medios técnicos para obtener la

\footnotetext{
7 CARRILlO, M.: «El derecho a la propia imagen como derecho fundamental», en: Revista jurídica de Asturias, número 18, 1994, pág. 18.

8 Pascual Medrano, A.: El derecho fundamental a la propia imagen. Fundamento, contenido, titularidad y límites, Thomson-Aranzadi, Pamplona, 2003, pág. 62.
} 
información. Con esta forma de proceder, la periodista no respetó los límites externos del derecho a la información (art. 20.2 CE) [sic $]^{9}$, que se cifran en el respeto a los derechos de la personalidad del art. $18 \mathrm{CE} »^{10}$. Este autor considera que la STC sobre la cámara oculta «es positiva en la medida que protege estos derechos de la personalidad en un contexto jurídico privado, frente al uso abusivo de las nuevas tecnologías audiovisuales» ${ }^{11}$.

Desde la perspectiva de los periodistas la limitación constitucional supone una graduación a su capacidad de elección de recursos con los que contribuir a la formación de la opinión pública, sin olvidar que, en todo caso, dicha finalidad debe estar presente como justificación de las decisiones que los profesionales de la Información hayan adoptado. En la Sentencia que se comenta se cita, como jurisprudencia de apoyo la idea de que toda intromisión en cualquier otro derecho fundamental debe ser congruente y no resultar exorbitante en atención al fin perseguido, la STC 185/2002, de 14 de octubre, FJ 3. En ella se desestimó la demanda de amparo solicitada por Cantábrico de Prensa, S.A., que había sido condenada por intromisión ilegítima en el honor de una víctima de un delito de agresión sexual.

Aun en los casos en los que se admite la intromisión en otros derechos por estar justificada, existe una ulterior exigencia al trabajo periodístico que consiste en que la afectación ha de ser la mínima posible para que permita conseguir el fin perseguido. Así lo recuerda de nuevo el Alto Tribunal y quedó ya establecido en la STC 156/2001, de 2 de julio, FJ 4, en la que Elena Riera Blume presentó un recurso de amparo alegando que entendía vulnerados sus derechos a la intimidad personal y a la propia imagen por parte de la revista Interviú tras la publicación de unas fotografías desnuda sin su consentimiento en el interior de un reportaje titulado «Sexo y negocios en nombre de Dios» y que entendió no estaba justificada por la libertad de información. El TC entendió vulnerados ambos derechos, pero otorgó el amparo parcialmente por medio de esta Sentencia, que contó con un voto particular ${ }^{12}$.

\footnotetext{
9 Se trata de un error, pues el artículo 20.2 CE prohíbe la censura previa.

10 CARrillo, M.: "Stop a la cámara oculta», en: Cuadernos de Periodistas, número 24, Asociación de la Prensa de Madrid, Madrid, 2012, pág. 38.

11 CARRILlO, M.: «Stop a la cámara...», pág. 37.

12 El formulado por el magistrado Vicente Conde Martín de Hijas, para quien sí se había producido una vulneración del derecho a la propia imagen de la demandante, pero no en el derecho a su intimidad personal.
} 
La conclusión del Alto Tribunal es clara. Al igual que la cámara oculta solo debe utilizarse como último recurso para obtener determinadas informaciones, a las que no se podría acceder de otro modo, también las intromisiones en cualquier derecho fundamental de terceros con ocasión del ejercicio del derecho a la libertad informativa deberán responder a los criterios de adecuación, necesidad y proporcionalidad para ser consideradas legítimas. De modo que solo se podrá conceder la protección constitucional cuando no exista ninguna otra vía para ejercer la libertad informativa sin proceder a una intromisión en los derechos de la personalidad que venimos citando. En caso contrario, deberá utilizarse con carácter previo.

Continúa el TC su exposición del FJ 6 apoyándose en las alegaciones que vertidas por el Ministerio Fiscal pretenden llamar la atención sobre la superior capacidad intrusiva que presenta la técnica investigadora periodística de la cámara oculta y que impide que quien es grabado en su voz e imagen pueda oponerse a estas actuaciones, puesto que todo el proceso informativo hasta el mismo momento de la emisión se mantiene de forma clandestina. A esta combinación se añade otro elemento más que no debe pasar inadvertido. Se refiere a la provocación previa de los periodistas, que supone el detonante de todo lo que después registran los modernos y pequeños instrumentos de captación.

Dejamos constancia en este punto de que medios de comunicación señalados en calidad de referentes del Periodismo autonómico, nacional, continental y mundial, como son, respectivamente, Canal Sur ${ }^{13}, R T V E^{14}, B B C$ o The New York Times, solo aceptan que se recurra a la cámara oculta para demostrar la comisión de prácticas delictivas o ilegales que tienen un destacado interés para el público y únicamente cuando no se disponga de otro modo para obtener para obtener dicha información. Es necesario acudir tanto a los códigos

13 En el libro de estilo de Canal Sur y Canal 2 Andalucía se puede leer: "Canal Sur TV y Canal 2 no emitirán imágenes grabadas por medios ilegales o conseguidas mediante cualquier ardid (cámara oculta, suplantación de personalidad, engaño...). Su emisión o los medios para conseguirlo solo está justificada, con autorización previa de la dirección de informativos, en casos de auténtico interés público pero no para airear intimidades particulares o escándalos intrascendentes de cualquier índole».

14 En el punto 2.6.3 del manual de estilo de RTVE se establece lo siguiente: «El uso de cámaras y micrófonos ocultos que impiden que una persona sepa que están siendo grabadas su imagen y sus palabras para su posterior emisión pública solo está justificado en casos muy especiales, como cuando se intenta demostrar la existencia de prácticas ilegales o delictivas que afectan al interés público. La cámara y el micrófono ocultos son el último recurso para probar una acusación o denuncia de verdadero interés público». 
deontológicos elaborados por asociaciones de periodistas como a las autorregulaciones de empresas informativas.

Un requisito adicional para el empleo de instrumentos de grabación escondidos consiste en la necesidad de aprobación previa para su empleo por parte de la dirección del medio. Es más, para la emisión de la filmación oculta se exige el consentimiento de las personas que aparezcan de modo reconocible en las imágenes grabadas con las cámaras emboscadas. En caso contrario, se les debe pixelar.

Para reflejar la trascendencia que tiene en la necesaria ponderación entre los derechos que están en conflicto la falta de consentimiento de quien ha sido grabado con una cámara o micrófono oculto, el TC cita de nuevo la STEDH de 24 de junio de 2004, así como la de 10 de mayo de 2011, Mosley contra el Reino Unido.

De la Sentencia Von Hannover contra Alemania se cita el apartado 68, donde el Tribunal con sede en Estrasburgo afirma que aunque la demanda que analiza no trate stricto sensu sobre dicha cuestión le resulta imposible abstraerse a la realidad de que las fotos a la princesa Carolina fueron tomadas en un contexto caracterizado por el desconocimiento y la falta de consentimiento de la protagonista, pero también de forma clandestina y con acceso de los objetivos de sus cámaras a un lugar cuya acceso para periodistas y fotógrafos estaba reglamentado de forma estricta. En línea similar se menciona el apartado 11 de la STEDH de 10 de mayo de 2011, en la que Mosley no obtuvo el reconocimiento que solicitó en cuanto a una presunta violación de su derecho a la intimidad por no haber sido informado previamente a la publicación de un reportaje del que era protagonista no deseado ${ }^{15}$.

El TC sigue su argumentación destacando que el acceso al lugar de grabación por parte de la periodista se produjo por medio de una simulación de identidad, sin que se tenga la certeza de que si se hubiera presentado como lo que verdaderamente era habría sido invitada a entrar en el ámbito reservado de la clínica en la que se pasaba consulta. Quizás la naturista tampoco hubiera accedido a ser entrevistada si se le hubieran expuesto las intenciones auténticas de la comunicadora.

Lo que subyace en el párrafo anterior es el llamado derecho a la autodeterminación informativa, cuya exigencia básica es que las relaciones interpersonales no se produzcan mediante engaños. Se trata de una creación jurisprudencial del Tribunal Constitucional

15 www.elpais.com, 10 de mayo de 2011. 
Alemán ${ }^{16}$ en 1983 mediante la modificación parcial del artículo 1.1 de la Ley Fundamental de Bonn (derecho a la intangibilidad de la dignidad humana) junto con el artículo 2.1 del mismo cuerpo legal, que proclama el libre desarrollo de la personalidad. El derecho protege la libertad individual de elección de destinatario de las conversaciones y de testigo de la esfera privada.

Juan Cruz, que no ha escatimado elogios para la STC 12/2012, es un firme defensor de la idea de que el periodista no puede tener por su condición más derechos que el resto de los ciudadanos para los que trabaja en el cumplimiento del derecho a la información de estos. Tan solo se admitirían aquellos privilegios que estén directamente ligados a dicha función: «A lo que únicamente nos faculta el carné (el de periodista, precisamente) es a obtener ciertas facilidades que, por otra parte, no suponen obligación alguna por parte de quienes las deparan. Y los que obtengamos debe ser siempre en buena lid, en función de nuestra capacidad para convencer a los otros de que la información que quisieran ocultar es relevante para la ciudadanía ${ }^{17}$.

El periodista de El País al que acabamos de citar ha justificado en el vacío legal existente hasta entonces las actuaciones periodísticas para obtener informaciones y cuyo proceder «era obtener supuestamente información o valoración que, con la cara descubierta, no hallaría de ningún modo ${ }^{18}$. Por ello considera muy oportuno el pronunciamiento del TC. Hay una frase a la que Cruz recurre con frecuencia y también lo ha hecho en su comentario a la Sentencia referida porque simplifica la función que para él desarrollan los profesionales de informar. La pronunció el periodista italiano Eugenio Scalfari a finales de los años ochenta del siglo pasado ${ }^{19}$ ante un grupo de estudiantes de la Universidad Autónoma de Madrid. Para el fundador del diario La Reppublica, los periodistas son «gente que le dice a la gente lo que le pasa a la gente ${ }^{20}$.

El TC continúa el desarrollo del FJ 6 de la Sentencia de referencia poniendo de manifiesto un hecho constatado como es que la capacidad de difusión por medio de la televisión del material obtenido con cámara oculta resulta muy superior al de la prensa escrita.

\footnotetext{
16 Bundesverfassungsgericht.

17 CRUZ, J.: «El fin de la vida privada», en: Cuadernos de Periodistas, número 24, Asociación de la Prensa de Madrid, Madrid, 2012, pág. 23.

18 Opus cit., pág. 22.

19 No se ha podido determinar la fecha exacta de ese encuentro. En cualquier caso, Scalfari utiliza la definición reproducida después en ese mismo párrafo con frecuencia y es la cita por la que más se le conoce.

20 www.elpais.com, 15 de febrero de 2009.
} 
Recuerda que así quedó de manifiesto en la ya mencionada (en FJ 5) STEDH de Jersild contra Dinamarca, apartado 31. En esta resolución se aplicó el llamado efecto guillotina del artículo 17 del CEDH, que permite sancionar de forma inmediata y definitiva el abuso de derecho. Los hechos consistieron en que un grupo de ciudadanos daneses mostró comportamientos racistas hacia los negros que fueron difundidos a través de un programa de televisión. El Tribunal de Estrasburgo negó a los primeros su derecho a la libertad de expresión reconocido en el célebre artículo 10 de dicho CEDH. No obstante, al instigador de la emisión audiovisual no se le consideró ni culpable ni responsable de los actos.

El TC no llega a utilizar el término técnico en el mundo de los medios de comunicación de porcentajes de audiencia, pero sí constata que diez años después de los hechos de Dinamarca con la STEDH Von Hannover contra Alemania, apartado 70, también se demostró que el uso invasivo de las nuevas tecnologías permite obtener unas imágenes que se difunden a amplios segmentos de la población.

Antes de finalizar este FJ 6 el Alto Tribunal da por bueno el argumento esgrimido en el recurso de amparo sobre la libertad de elección de técnicas de la que disponen los periodistas para elaborar sus informaciones, tal y como estableció el TEDH. No obstante, completa esta afirmación con dos matizaciones que suponen un cambio radical y que emanan de la misma fuente jurídica continental. La primera es que esta potestad se mantendrá siempre que se cumplan las exigencias de objetividad y neutralidad. Así lo expresó el apartado 34 de la STEDH Jersild contra Dinamarca.

El segundo nivel, que consideramos más trascendente, viene impuesto por los límites deontológicos. Procede, en primer lugar, situar la base argumental citada, que se inicia de nuevo con la STEDH Mosley contra Reino Unido, apartado 113, en este caso, y también la Sentencia del Tribunal de Estrasburgo de 18 de enero de 2001, MGN Limited contra Reino Unido, apartado 141. Este caso llegó a la justicia europea después de que el Daily Mirror publicara unas fotografías de la británica Naomi Campbell a la salida de una reunión de Narcotics Anonymous, donde participaba de forma secreta. El rotativo sensacionalista fue condenado en el Reino Unido por una intromisión en la intimidad de la modelo, por lo que recurrió al TEDH, que desestimó la petición en cuanto al fondo del asunto, pero decidió que se rebajasen las costas judiciales que debía abonar por entender excesivos los honorarios pactados entre Campbell y sus abogados. 
Ha llegado el momento de reflejar la trascendencia de este último párrafo del FJ 6 de la STC 12/2012, y de forma muy especial sus últimas líneas. Se refieren, sin nombrarla, a la cámara oculta: en ningún caso pueden considerarse legítimas aquellas técnicas que invaden derechos protegidos, ni aquellos métodos que vulneren las exigencias de la ética periodística en cuanto a la solvencia y objetividad del contenido informativo.

Conociendo el fallo de esta Sentencia y leyendo toda su argumentación desarrollada hasta aquí, nos bastaba para afirmar que el TC asumía en su totalidad el pronunciamiento del TS sometido a enjuiciamiento, pues, como ha afirmado Manuel Miranda Estrampes ${ }^{21}$, con respecto a la cámara oculta hacía suyo el resultado negativo de «un riguroso test de imprescindibilidad o necesariedad, que no se cumplía en el caso analizado, al no ser necesaria para obtener la información, pero no fundamentó su decisión en una prohibición absoluta de utilización de dicho método en la actividad periodística, de raigambre constitucional $»^{22}$. Sin embargo el Alto Tribunal da un paso adelante y llega mucho más lejos pues parece proceder al desmantelamiento de toda la ingeniería que sustenta el uso de los instrumentos de grabación escondidos.

El TC ha encontrado, por tanto, en la jurisprudencia del TEDH las justificaciones para cuestionar el uso (abuso debería decirse) de muchos periodistas de la cámara oculta y que en este caso le llevará a denegar los amparos solicitados. No obstante, la cita del párrafo anterior debe ponerse en relación, como haremos, con la que será última frase de la Sentencia con calado jurídico antes de dar paso al fallo.

Además de las implicaciones jurídicas reseñadas, este abuso de los periodistas que consiste en servirse de las técnicas invasivas para llegar tan lejos tiene también unas consecuencias negativas sobre las que ha reflexionado Marlasca: «Porque el periodismo -sin apellidos- se basa en algo que los años de plomo de las cámaras ocultas han puesto en serio peligro [...]: la confianza entre el periodista y las fuentes de información ${ }^{23}$.

La utilización de la expresión «sin apellidos» tiene su explicación. Este periodista de investigación, antes de considerar que la cámara

\footnotetext{
21 Fiscal ante el Tribunal Constitucional.

22 Miranda Estrampes, M.: «Prohibición constitucional de la utilización de las cámaras ocultas en la actividad periodística. ¿Fin del periodismo de investigación?», en: Diario La Ley, número 7.839, Wolters Kluwer España, Las Rozas (Madrid), 17 de abril de 2012, pág. 4.

23 Marlasca, M.: «Ni periodismo, ni investigación», en: Cuadernos de Periodistas, número 24, Asociación de la Prensa de Madrid, Madrid, 2012, pág. 26.
} 
oculta ha hecho mucho daño a su sector, prefiere realizar una distinción periodística con carácter previo: «Soy de los que piensa [...] que solo hay dos tipos de periodismo: el bueno y el malo. Así que nunca he creído en la existencia de ese subgénero llamado periodismo de investigación, porque el buen periodismo implica en ocasiones la realización de tareas destinadas a investigar: búsquedas en fuentes abiertas y cerradas, acceso a documentación reservada... Pero todo eso no es más que una forma de ejercer el periodismo» ${ }^{24}$.

Marlasca valora de forma positiva la STC 12/2012, pues opina que puede contribuir a devolver el ejercicio periodístico a la que fue su premisa inicial y que por lo que respecta al profesional de la Información, sería así: «tú (fuente) me cuentas a mí (periodista) algo, a sabiendas de que yo me dedico a difundir noticias y, por tanto, lo que me cuentes, con mis prevenciones, mis filtros y mis comprobaciones, tiene muchas posibilidades de ser publicado» ${ }^{25}$.

Al margen de consideraciones jurídicas, los efectos perniciosos que puede provocar en el Periodismo el abuso de instrumentos de grabación escondidos también son advertidos desde fuera de la profesión. Así, Marta Gómez de Liaño Fonseca-Herrero afirma que «la realidad ha demostrado como en muchas ocasiones el recurso a las cámaras ocultas evidencia, justamente, la ausencia total de investigación periodística, pues son utilizadas como instrumento de "facilitación" en la obtención de información, carente de cualquier esfuerzo de investigación serio, riguroso y de trascendencia social» ${ }^{26}$. Manuel Miranda Estrampes ya llamó la atención sobre esa probable falta de rigurosidad ${ }^{27}$.

\section{V.7. FJ 7: Por fin la ponderación entre los derechos fundamentales en conflicto}

Entramos ya en el FJ 7 y último de la Sentencia comentada. El Alto Tribunal afirma que ha llegado el momento de detenerse en las circunstancias concretas que han rodeado el ejercicio de la libertad

24 Opus cit., pág. 25.

25 Opus cit., pág. 26.

26 GÓMEZ DE LIAÑo FonSECA-HERRERO, M.: «La prohibición constitucional del uso de cámaras ocultas en el marco del denominado periodismo de investigación», en: Derecom (revista online), ISSN: 1988-2629, número 10, Nueva Época, junio-agosto, 2012, pág. 9.

27 Miranda Estrampes, M.: «Legitimidad del empleo de sistemas de captación de la imagen y el sonido y su relación con los derechos a la intimidad y a la propia imagen», Diario La Ley, número 7.674, 2011, Referencia D-296, pág. 7. 
de comunicación para proceder después a la necesaria ponderación. Tras este breve párrafo introductorio, el siguiente tiene una carga jurídica de consideración, pues confronta los conceptos de relevancia pública de la información y de la veracidad de su contenido.

Se informa que a lo largo de todo el iter procesal que llegan a su fin en la jurisdicción española, los ahora recurrentes han insistido en la veracidad del contenido del reportaje, sin que se haya producido controversia jurídica alguna por esta cuestión. No obstante, no se sitúa aquí el elemento decisorio. La razón de ello es la jurisprudencia continuada del TC consistente en descartar la veracidad del contenido de la información divulgada como cuestión trascendente para resolver un conflicto de derechos cuando se afecta el derecho a la intimidad y prestar atención a la relevancia pública informativa. Sería distinto si en vez de una posible lesión de la intimidad se estuviera enjuiciando una intromisión en el derecho al honor, pues en este caso la presencia de lo veraz sí se considera un elemento reductor.

El párrafo de la Sentencia que se está comentando se cierra con la referencia por el TC a su STC 185/2002, de 14 de octubre, que en el FJ 4 y último dejó expuesta la consideración de la veracidad como presupuesto de la lesión del derecho a la intimidad siguiendo una línea jurisprudencial marcada antes por las SSTC 197/1991, de 17 de octubre, FJ 2 y 115/2000, de 10 de mayo, FJ 7.

Recogemos en este punto una de las reducidas opiniones contrarias a la Sentencia comentada que reúnen la doble condición de proceder de profesionales de la Información y utilizar en su argumentación no solo conceptos periodísticos, sino también jurídicos. Eso sí, tenemos que hacer la salvedad, no baladí, de que su autor fue nada menos que parte implicada, pues se trata de Melchor Miralles ${ }^{28}$, que como director de la productora $E l$ Mundo $T V$, fue el principal responsable del programa de televisión en el que se difundieron las imágenes grabadas con cámara oculta en la consulta de la naturista.

Considera que en la ponderación de derechos fundamentales el TC no ha valorado el derecho a la información de los ciudadanos: «es un error de grueso calibre confrontar solo los derechos de una persona con los de los periodistas, olvidando el derecho esencial en juego para encontrar una solución jurídica y deontológica ade-

28 En el momento en el que la STC 12/2012 fue pronunciada, Melchor Miralles era director y presentador en la cadena de radio desaparecida $A B C$ Punto Radio del programa matinal diario Cada mañana sale el sol. 
cuada para salvaguardar el derecho de todos a estar informados $»^{29}$. Afirma, sin ningún atisbo de duda, que llegarán otras resoluciones judiciales que crearán jurisprudencia en el sentido contrario.

Miralles llega a utilizar los términos de «dislate jurídico» ${ }^{30} \mathrm{y}$ «disparate lamentable» ${ }^{31}$ para referirse a la Sentencia del Alto Tribunal, después de informar en su artículo que solo estudió hasta cuarto curso de Derecho y que considera que en el mundo de las leyes «casi todo es discutible» ${ }^{32}$. La justificación de sus críticas de modo resumido consiste en entender que de los tres derechos fundamentales que estaban en juego, no se ha producido una valoración del derecho a la información.

No obstante, el periodista desarrolla su argumentación de forma tan imprecisa que quizás merecería recibir de vuelta alguna de las calificaciones que ha dedicado a la Sentencia del TC. Sobre esta señala que de los tres derechos fundamentales que recoge la CE y que enumera «solo han colocado en la balanza los dos primeros: el derecho a la intimidad y a la propia imagen, el derecho a la libertad de información y expresión... (sic) y el derecho, esencial en un sistema democrático, de los ciudadanos a recibir información veraz» ${ }^{33}$. Para Miralles, el derecho a la intimidad y el derecho a la propia imagen formarían parte de un único derecho, el segundo sería la libertad de expresión (ambos valorados) y el tercero el derecho de la ciudadanía a recibir información veraz (el no ponderado, en su opinión). De este último llega a informar que es el más importante de todos.

Llama la atención, al menos prima facie, una cierta coincidencia con la crítica de Miralles por parte de Manuel Núñez Encabo ${ }^{34}$, quien considera que la Sentencia es incompleta porque el TC se ha centrado en los derechos de la personalidad de la titular de la consulta, sin valorar la relevancia pública del tema investigado: «no ha ponderado el derecho a la intimidad o la imagen con el de los periodistas a informar y el de los ciudadanos a recibir información veraz y de interés público» ${ }^{35}$. Se pregunta también «si el derecho a la

29 Miralles, M.: «Volveré a utilizar cámaras ocultas», en: Cuadernos de Periodistas, número 24, Asociación de la Prensa de Madrid, Madrid, 2012, pág. 30.

30 Ibídem.

31 Opus cit., pág. 31.

32 Opus cit., pág. 29.

33 Opus cit., pág. 30.

34 Opina en su condición de presidente de la Comisión de Arbitraje, Quejas y Deontología de la FAPE, aunque también es catedrático de Ciencias Jurídicas en la Universidad Complutense de Madrid.

35 Cita obtenida del reportaje titulado "El periodista no puede hacer de sheriff», firmado por María R. Sahuquillo y Rosario G. Gómez, en: www.elpais.com, 10 de febrero de 2012. 
imagen de la esteticista se corresponde con su imagen verdadera, o es prioritario el derecho de los ciudadanos a estar informados de la verdad de su imagen ${ }^{36}$.

El siguiente punto por aclarar es el de la valoración del presunto interés general del reportaje elaborado con cámara oculta. El TC es rápido aquí para aclarar desde el principio, que al margen de la relevancia pública que envuelve a la información, el dato que debe prevalecer es que la forma en la que fue obtenida y almacenada (con cámara oculta) supuso, sin ninguna duda, una intromisión en el derecho a la intimidad personal y a la propia imagen. Juan Manuel Fernández Martínez ya había llamado la atención sobre el hecho de que cualquier simple invocación al interés general parecía equivaler «a otorgar un cheque en blanco en el uso de las cámaras ocultas» ${ }^{37}$.

Con la afirmación del párrafo anterior, que no deja espacio para la interpretación, el Alto Tribunal va más allá de lo que lo había hecho el TS, que también concluyó que hubo intromisión ilegítima en tales derechos pues la información carecía de relevancia para que imágenes de ella fueran difundidas en televisión. En cualquier caso, ahora el TC rechaza los argumentos de los recurrentes para justificar que no se produjo tal vulneración del derecho a la intimidad. Estos son: al acceso del público a la parte de la vivienda donde la esteticista pasaba consulta y que la presunta relación profesional que se pudo establecer entre esta y la periodista camuflada como paciente fuera más allá del ámbito constitucionalmente protegido para relaciones de carácter profesional.

Aquí el intérprete máximo de la CE hace suya la conclusión del TS, que en la Sentencia impugnada calificó como estrictamente privada la relación entre la periodista y la naturista. A esta idea se enlaza el hecho no controvertido de que no se presentó ningún tipo de consentimiento expreso, ni tampoco válido o eficaz, por parte de la titular del derecho cuestionado para la grabación en la consulta, con lo que la incógnita queda despejada con la afirmación de que se vulneró ilegítimamente el derecho del artículo 18.1 CE sobre el que ahora se discutía.

Cuatro líneas y media bastan en el siguiente párrafo para llegar a una idéntica conclusión sobre el derecho a la propia imagen. Entiende el TC que el TS valoró correctamente las circunstancias del caso. El motivo único es que la naturista que fue grabada subrepti-

\footnotetext{
36 Ibidem.

37 Fernández Martínez, J. M.: «Empleo de cámaras ocultas en reportajes periodísticos», en: Revista Aranzadi Doctrinal, número 2/2009, pág. 7.
} 
ciamente no tuvo oportunidad de pronunciarse sobre si consentía o no que la representación de su aspecto físico y de su voz fuera reproducida en el programa de televisión. En definitiva, no estuvo en su mano la posibilidad de impedir ser identificada por los espectadores.

Hemos llegado al penúltimo párrafo de la fundamentación jurídica, al que ya hemos aludido con anterioridad. Con él concluye la labor interpretativa del Alto Tribunal antes de emitir su decisión definitiva. Se mantiene aquí también la valoración realizada por la Sala de lo Civil del TS, que consistió en la negación de la solicitada prevalencia de la libertad de información. Aquí es donde la STC 12/2012 deja su impronta con un mensaje que ha suscitado reacciones de una gama muy variada.

La secuencia es como sigue. Hay un criterio que de por sí resulta suficiente, con independencia de que lo investigado por la comunicadora tuviera o no relevancia pública, para que la libertad informativa ceda en la ponderación ante los derechos del artículo 18.1 CE, tal y como ya estableció la Sentencia impugnada. Nos referimos a que la captación intrusiva de imágenes y sonidos con cámara oculta no resultaba imprescindible para conocer la actividad desarrollada. Se recoge aquí incluso como aportación periodística una idea que hubiera contribuido a llegar a un destino similar, sin haber camuflado instrumentos de grabación: la realización de entrevistas a los clientes (el TC no habla de pacientes) de la naturista.

Y es aquí donde llega la afirmación de más calado jurídico de las que realiza el Alto Tribunal, y no solo por el lugar estratégico en el que ha sido ubicada, justo antes de afirmar en el último párrafo que da paso al fallo que la restricción que impuso la STS a los recurrentes estaba constitucionalmente justificada: lo que está constitucionalmente prohibido es justamente la utilización del método mismo (cámara oculta) por las razones que antes hemos expuesto.

Ya se afirmó, en opinión de Rebollo Delgado, la incompatibilidad entre las sentencias judiciales y los titulares informativos. La lectura, el manejo o la elaboración de ambos tipos de documentos permiten llegar a una primera diferencia estructural. El titular pretende incorporar en un espacio limitado la esencia de una información que a continuación será desarrollada, con un método deductivo, con la fórmula de la pirámide invertida, comenzando por lo más trascendente hasta llegar a lo anecdótico, puntual o menos importante. En los pronunciamientos judiciales sucede lo contrario, como si se tratase de un relato o un estreno cinematográfico, el clímax estará muy próximo al fallo. Aquí la técnica es inductiva. 
En la frase que hemos entrecomillado de la Sentencia es donde la prensa encontró el caldo de cultivo para seleccionar los titulares de sus informaciones y comentarios sobre ella. Se pudieron leer frases del estilo de: «El Tribunal Constitucional prohíbe el periodismo de investigación», «El Tribunal Constitucional declara ilegítimo el uso de la cámara oculta» o «El periodista no puede hacer de sheriff».

Miralles ha dejado una frase en su comentario que habría servido como un titular periodístico llamativo en caso de que la hubiera pronunciado como respuesta en una entrevista. Y él también la incluyó casi al final, como si fuera una de sus conclusiones sobre la Sentencia. Tras decir que reduce la libertad de los ciudadanos, limita el ejercicio de la actividad periodística y que se puede considerar una extralimitación de sus funciones, proclama lo siguiente: «...y es un ejercicio de censura inaceptable en un sistema democrático, en un Estado de derecho» ${ }^{38}$.

A lo que acaba de afirmarse se puede contraponer lo afirmado por Miranda Estrampes: "esta equiparación que se hace entre cámara oculta y periodismo de investigación es rechazable por su carácter marcadamente simplista. No siempre el periodismo de investigación exige de la utilización de dicho método, y no siempre la utilización de la cámara oculta puede calificarse de periodismo de investigación ${ }^{39}$.

Este posible titular podría entrar en colisión con otro dejado también por Miralles a la hora de encabezar una supuesta entrevista en la que el director a la sazón de la productora enjuiciada hubiera respondido lo que él mismo ha escrito: «Los diferentes mecanismos técnicos o tecnológicos a disposición de los profesionales de la información no son objeto, ni en España ni en ningún país del planeta, de protección constitucional, sino un asunto referido a legislación ordinaria y, en consecuencia, ajena al ámbito competencial del TC» ${ }^{40}$.

En cualquier caso, la frase que sirve como colofón a la STC 12/2012 resulta sorprendente, por inesperada, pero también por desproporcionada y por su presencia justo al final. Podríamos decir también que sin anestesia previa para aquellos a los que más puede afectar. Quizás no habría llamado la atención si se hubiera colocado antes y con una justificación documentada.

\footnotetext{
38 Opus cit., pág. 31.

39 Miranda Estrampes, M.: «Prohibición constitucional de la ...», pág. 5.

40 Opus cit., pág. 30.
} 
Ana Azurmendi Adarraga ha señalado que las razones de lo que ella llama coletilla mortal hay que buscarlas en el TEDH, en concreto en las dos Sentencias suyas que han sido citadas por el TC a lo largo de su fundamentación jurídica (ambas por unos hechos ocurridos en el Reino Unido): «Que en ningún caso pueden considerarse legítimas aquellas técnicas que invaden derechos protegidos, ni aquellos métodos que vulneren las exigencias de la ética periodística en cuanto a la solvencia y objetividad del contenido informativo» ${ }^{41}$.

No obstante, parece claro que esta afirmación incluida al final, ni responde a un descuido ni tampoco es fruto de la casualidad. Los magistrados la han colocado ahí de forma intencionada. A pesar de su claridad, se pueden plantear al menos tres cuestiones que quedan en el aire para los próximos pronunciamientos que el TC ya tiene pendientes de resolución: las grabaciones con cámara oculta realizadas en lugares públicos y abiertos no sometidos a la protección de la intimidad personal; aquellas otras en las que su utilización sea verdaderamente el único recurso del que dispone el periodista para hacer averiguaciones y exponerlas a la opinión pública; o también los supuestos en los que de forma clara la temática sí es de interés general. Se comprobará entonces si mantiene la doctrina o le incorpora algún tipo de matizaciones.

\section{V.8. Resumen de los Fundamentos Jurídicos}

- En el breve FJ 1 se informa que quienes recurren consideran que se ha violado su derecho a comunicar libremente información veraz por la aplicación de unos criterios de ponderación y proporcionalidad que no se ajustan a la jurisprudencia. El Ministerio Fiscal propone la desestimación absoluta.

- La controversia jurídica queda acotada en el FJ 2, donde se afirma que el objeto del pronunciamiento será la valoración de si en la STS de la que traen causa los recursos de amparo se ha vulnerado o no el artículo 20.1.d) CE en su concreción de derecho a la libertad de información.

- La particularidad del objeto de estudio, que obliga por primera vez al Alto Tribunal a pronunciarse sobre el empleo de una cámara oculta que ha grabado imágenes y sonidos en una

41 AzURmendi AdARRAGA, A.: «La coletilla mortal», en: www.unav.es, 11 de febrero de 2012. 
esfera privada en la que se realiza una actividad profesional se recoge en el FJ 3 de la STC 12/2012.

- El FJ 4 se dedica a recordar los criterios que la jurisprudencia constitucional aplica a la valoración individual de los tres requisitos necesarios para que en un trabajo periodístico prevalezca el derecho a la información sobre los derechos de la personalidad del artículo $18 \mathrm{CE}$. Se refiere a la veracidad de lo comunicado, su interés general y la relevación pública del hecho noticioso.

- A partir del quinto FJ se analizan los hechos que han dado origen a la STS enjuiciada por el TC. En primer lugar, se determina la existencia de una vulneración del derecho a la intimidad personal con la grabación de una conversación con cámara oculta en el ámbito privado del despacho profesional. La misma conclusión se alcanza con respecto al derecho a la propia imagen por la captación visual y acústica sin la previa obtención del consentimiento. La difusión posterior provocó la que la lesión alcanzara una intensidad alta.

- En el FJ 6 el intérprete supremo de la CE recuerda que el derecho a la libertad informativa solo está legitimado para realizar intromisiones en derechos fundamentales de terceros, como son los relativos a la personalidad, si se aplican criterios de adecuación, necesidad y proporcionalidad. En las últimas líneas se recurre a la jurisprudencia del TEDH para afirmar que la libertad periodística en la elección de técnicas con las que hacer la transmisión informativa tiene unos límites que van más allá de la invasión de derechos protegidos y alcanzan también el respeto a los principios de ética periodística.

- Por último, en el FJ 7 tras aplicar la esperada ponderación entre los derechos fundamentales en colisión se procede a la resolución de la Sentencia con la desestimación de los recursos de amparo por entender que la captación intrusiva merece ser considerada innecesaria, inadecuada y llega a prohibirla en este supuesto concreto.

\section{A MODO DE CONCLUSIÓN}

La STC 12/2012 no acaba de forma generalizada con el periodismo de investigación a través de las grabaciones videográficas íntegras realizadas con engaño e instrumentos camuflados, la llamada 
captación intrusiva. Sin embargo, sí deja prácticamente cerradas las vías de progreso jurídico cuando se capten las imágenes y sonidos de personas que no tengan relevancia pública y no se realicen en lugares públicos. En estos casos el fin no justificará los medios.

Otro tradicional sustento jurídico para justificar las actuaciones periodísticas ha venido representado por el derecho a la información que los periodistas ejercen en beneficio de la ciudadanía. Al margen de las grabaciones con cámara oculta, solía ser el derecho beneficiado cuando los tribunales tenían que decidir entre la trascendencia de su ejercicio y la vulneración de uno o varios de los derechos de la personalidad del artículo 18.1 CE.

Con este pronunciamiento el TC parece cerrar el período en el que había abandonado la técnica ponderativa. Su conclusión es clara al censurar que se haya producido una desviación del objeto que tenía la información, es decir, que aquí mismo radica la vulneración de los derechos fundamentales en juego.

Para los supuestos en los que los fallos judiciales no eran exactamente de este modo, la presencia del derecho a informar servía para mitigar sobremanera las consecuencias económicas de una condena. Tanto es así que estas podrían ser incluidas como un coste más en el presupuesto de cualquier trabajo periodístico. La Sentencia analizada viene a recordar en este sentido el giro jurisprudencial a la hora de interpretar una misma normativa, que responde a una nueva realidad de consolidación democrática no precisada de un supuesto trato de favor del derecho a la información de todos frente a otros derechos fundamentales.

La Sentencia no condiciona futuros pronunciamientos del TC sobre el empleo de cámara oculta. En ella el Alto Tribunal ha entendido que deben prevalecer el derecho a la intimidad personal y el derecho a la propia imagen sobre el derecho a la información. Esto es así por la mencionada conducta subrepticia del informador, que no se ajustó a los más mínimos parámetros de necesidad y adecuación exigibles, con el resultado de violación de derechos fundamentales de la personalidad. Y todo ello sin necesidad de establecer una vinculación directa con la mayor o menor relevancia pública de las investigaciones periodísticas realizadas con el método de la cámara oculta, que es el que sufre en este caso la desaprobación constitucional.

No debe dudarse que en el futuro llegarán pronunciamientos del TC en los que quede avalado el empleo de cámaras ocultas como instrumento necesario para el trabajo profesional periodístico. Para ello 
será requisito imprescindible que el ejercicio del derecho a la información se realice con un mayor nivel de respeto respecto de los derechos a la intimidad y a la propia imagen de las personas que son grabadas con utensilios que han permanecido ajenos a su vista y conocimiento. Pero también una mayor trascendencia social que en el caso analizado del hecho noticioso que se hace llegar a la opinión pública.

Es posible que la decisión judicial hubiera sido diferente si las empresas de comunicación solo hubieran divulgado la información noticiosa y veraz obtenida, pero con la reserva de las imágenes y sonidos grabados con cámara oculta como prueba de la veracidad de los hechos denunciados. Este uso del secreto periodístico podría haber permitido la concesión del amparo del artículo 20.1 d). CE a los informadores. Es decir, ya no se podría afirmar que el fin no justificaba los medios.

\section{BIBLIOGRAFÍA}

AZURMENDI ADARRAGA, A.: «La coletilla mortal», en: www.unav.es, 11 de febrero de 2012.

CARRILLO, M.: «El derecho a la propia imagen como derecho fundamental», en: Revista Jurídica de Asturias, número 18, 1994, pág. 18.

— «Stop a la cámara oculta», en: Cuadernos de Periodistas, número 24, Asociación de la Prensa de Madrid, Madrid, 2012, págs. 36-38.

CRUZ, J.: «El fin de la vida privada», en: Cuadernos de Periodistas, número 24, Asociación de la Prensa de Madrid, Madrid, 2012, págs. 22-24.

FERNÁNDEZ MARTÍNEZ, J. M.: «Empleo de cámaras ocultas en reportajes periodísticos «», en: Revista Aranzadi Doctrinal, número 2/2009, pág. 7.

GÓMEZ DE LIAÑO FONSECA-HERRERO, M.: «La prohibición constitucional del uso de cámaras ocultas en el marco del denominado periodismo de investigación», en: Derecom (revista online), ISSN: 1988.2629, número 10, Nueva Época, junio-agosto, 2012, págs. 1-17.

MACÍAS CASTILLO, A.: El derecho a la información y el reportaje con cámara oculta, Práctica de Derecho de Daños, n. ${ }^{\circ} 31$, octubre 2005. 
MARLASCA M.: «Ni periodismo ni investigación», en: Cuadernos de Periodistas, número 24, Asociación de la Prensa de Madrid, Madrid, 2012, págs. 25-28.

MIRALLES, M.: «Volveré a utilizar cámaras ocultas», en: Cuadernos de Periodistas, número 24, Asociación de la Prensa de Madrid, Madrid, 2012, págs. 29-31.

MIRANDA ESTAMPRES, M.: «Legitimidad del empleo de sistemas de captación de la imagen y el sonido y su relación con los derechos a la intimidad y a la propia imagen», Diario La Ley, número 7.674, 2011, Referencia D-296, pág. 7.

- «Prohibición constitucional de la utilización de las cámaras ocultas en la actividad periodística. ¿Fin del periodismo de investigación?», en: Diario La Ley, número 7.839, Wolters Kluver España, Las Rozas (Madrid), 17 de abril de 2012, págs. 3-5.

PASCUAL MEDRANO, A.: El derecho fundamental a la propia imagen. Fundamento, contenido, titularidad y limites, Thomson-Aranzadi, Pamplona, 2003.

REBOLLO DELGADO, L.: «Ni prohíbe el uso de cámaras ocultas, ni cercena el periodismo de investigación», en: Cuadernos de Periodistas, número 24, Asociación de la Prensa de Madrid, Madrid, 2012, págs. 42-45.

SEIDEL, C.: Datenbanken und Datenshutz, Frankfurt, 1974.

TIMOTEO ÁLVAREZ, J.: Historia y modelos de la comunicación en el siglo XX. El nuevo orden informativo, Ariel Comunicación, Barcelona, 1987.

TORRES DEL MORAL, A. y otros: Libertades informativas, Colex, Madrid, 2009.

URÍAS, J.: Lecciones de Derecho de la Información, Tecnos, Madrid, 2009. 
